\title{
Large scale distribution of bacterial communities in the upper Paraná River floodplain
}

\author{
Josiane Barros Chiaramonte $^{1}$, Maria do Carmo Roberto², Thomaz Aurélio Pagioro $^{3}$ \\ ${ }^{1}$ Programa de Pós-Graduação em Ecologia de Ambientes Aquáticos Continentais, \\ Universidade Estadual de Maringá, Maringá, PR, Brazil. \\ ${ }^{2}$ Programa de Pós Graduação em Ecologia de Ambientes Aquáticos Continentais, Departamento de \\ Biologia, Núcleo de Pesquisa em Limnologia Ictiologia e Aquicultura, Universidade Estadual de \\ Maringá, Maringá, PR, Brazil. \\ ${ }^{3}$ Departamento Acadêmico de Química e Biologia, Universidade Tecnológica Federal do Paraná,
} Curitiba, PR, Brazil.

\begin{abstract}
A bacterial community has a central role in nutrient cycle in aquatic habitats. Therefore, it is important to analyze how this community is distributed throughout different locations. Thirty-six different sites in the upper Paraná River floodplain were surveyed to determine the influence of environmental variable in bacterial community composition. The sites are classified as rivers, channels, and floodplain lakes connected or unconnected to the main river channel. The bacterial community structure was analyzed by fluorescent in situ hybridization (FISH) technique, based on frequency of the main domains Bacteria and Archaea, and subdivisions of the phylum Proteobacteria (Alpha-proteobacteria, Beta-proteobacteria, Gamma-proteobacteria) and the Cytophaga-Flavobacterium cluster. It has been demonstrated that the bacterial community differed in density and frequency of the studied groups. And these differences responded to distinct characteristics of the three main rivers of the floodplain as well as to the classification of the environments found in this floodplain. We conclude that dissimilarities in the bacterial community structure are related to environmental heterogeneity, and the limnological variables that most predicted bacterial communities in the upper Paraná River floodplain was total and ammoniacal nitrogen, orthophosphate and chlorophyll-a.
\end{abstract}

Key words: bacterioplankton distribution, floodplain, fluorescent in situ hybridization.

\section{Introduction}

Bacteria could be considered as a base in planktonic food chains in many aquatic ecosystems, having an important role in the carbon cycle to the atmosphere. In floodplain environments, for instance, heterotrophic bacteria may be an important link for dissolved organic matter to return to higher trophic levels through the microbial loop (Azam et al., 1983, Cotner and Bidanda, 2002).

Several studies have demonstrated that bacterioplankton communities differ in density in floodplains. These variations might be due to nutrient content and carbon quality (Teixeira et al., 2011), the origin (autochtho- nous and allochthonous) of the carbon present in floodplain lakes (Carvalho et al., 2003), and the period of the hydrological pulse (Anésio et al., 1996; Kobayashi et al., 2009, Palijan and Fuks, 2006). Still few studies focused in the structure of this community in floodplain systems.

Differences in bacterial community composition may be caused by physical and chemical characteristics of the water (Nelson et al., 2006, Shade et al., 2007), by the composition of other planktonic communities (Kent and Jones, 2006; Newton et al., 2006), algae biomass, organic and inorganic nutrients (Besemer et al., 2005), trophic state and humic content (Haukka et al., 2005). In addition, many studies about bacterial communities also state that their di- 
versity may be influenced by geographical distances (Oda et al., 2003, Papke et al., 2003, Whitaker et al., 2003).

The upper Paraná River floodplain is a very extensive floodplain system that presents a great variety of environments, classified as floodplain lakes, channels, rivers, and others environments entirely covered by aquatic vegetation and transition, terrestrial and riparian zones (Thomaz et al., 2007). The different environments found in this floodplain are different in the physical and chemical properties of the water, its depth, flow and connectivity to the main river channel (Thomaz et al., 2007, Tockner et al., 2000). The upper Parana River floodplain comprises three different main rivers, each one presenting different limnological characteristics that may increase even more the heterogeneity of the floodplain in large scale studies (Roberto et al., 2009). Because of these differences, bacterial communities in different environments in this floodplain may also present distinct patterns of distribution.

Although differences in bacterial communities between two floodplain lakes in the Paraná River floodplain have already been observed before by Lemke et al. (2009), few studies about bacterial community structure was done in other floodplain environments. The influence of the different rivers on bacterial community structure in the upper Paraná River floodplain wasn't considered yet.

We performed a characterization of bacterioplankton communities on the frequencies of the main bacterial groups in 36 sites in the upper Paraná River floodplain in order to i) verify the existence of differences in bacterial community structure throughout the studied sites, ii) evaluate spatial distribution of bacterial community structure, iii) observe whether environmental dissimilarities promote dissimilarities in bacterial communities and iv) identify which set of environmental factors influences bacterial community structures the most.

\section{Materials and Methods}

\section{Study area}

The study was performed in different environments on the upper Paraná River floodplain (Figure 1). These environments differ in depth, flux velocity, and connectivity. In addition, the large variety of physical and chemical features caused by the three main rivers that comprise this floodplain, generate a great heterogeneity when large scale studies are performed (Roberto et al., 2009). We considered three subsystems (Paraná, Baía and Ivinhema) regarding these rivers and their influence on the environments. The area of this study is located in the Paraná River floodplain downstream to the mouth of the Paranapanema River up to the first junction of Ivinhema River with the Paraná River. Sampling sites and their main features are found in Table 1.

\section{Samples}

The samples were collected in 36 different sites in the upper Paraná River floodplain, in December 2010, during a Long Term Ecological Research (LTER). Four samples were collected in the surface $( \pm 0.15 \mathrm{~m}$ depth $)$ at each site (three to analyze bacterial community and one for limnological analysis).

\section{Limnological Analysis}

Water level variations were obtained from data collected in a fluviometric ruler located in the Nupelia Field Laboratory, in Porto Rico, state of Paraná.

We measured water temperature (T), dissolved oxygen (DO), pH and electrical conductivity (Cond.) through portable potentiometers (YSI). Water transparency was assessed through Secchi disc depth and total alkalinity (Alk.) estimated through using Gran titration and calculated with inorganic carbon (Carmouze, 1995).

The water samples collected for limnological analysis in each site were kept in dark coolers. These samples were used to determine total, organic and inorganic suspended material concentration (TSM, OSM and ISM) according to Wetzel and Likens (Wetzel e Likens, 1990); and chlorophyll-a (Chl- $a$ ) according to Golterman, Clymo and Ohnstad (1978). Total Nitrogen and Nitrate ( $\mathrm{TN}$ and $\mathrm{NO}_{3}{ }^{-}$) were determined by spectrophotometer (Zagatto et al., 1981) and ammoniacal nitrogen concentrations $\left(\mathrm{N}^{-} \mathrm{NH}_{4}{ }^{+}\right)$ were measured according to Mackereth, Heron and Talling (1978). Total Phosphorus and Orthophosphate (TP and $\mathrm{PO}_{4}{ }^{3-}$ ) were determined by spectrophotometer according to Golterman, Clymo and Ohnstad (1978).

\section{Bacterial community}

We performed the FISH technique in order to analyze planktonic bacterial community based on Pernthaler et al. (2001) with some adaptations. Samples were fixed with paraformaldehyde (final concentration 2\%) and kept at $4{ }^{\circ} \mathrm{C}$ for about $24 \mathrm{~h}$, and then concentrated in white polycarbonate membranes $(0.2 \mu \mathrm{m}, 25 \mathrm{~mm}$, Whatman $)$. Membranes were kept frozen until analysis in the laboratory was performed.

The membranes were divided and each piece received a treatment with a probe to a bacterial division and hybridization buffer solution $(0.9 \mathrm{M} \mathrm{NaCl}, 20 \mathrm{mM}$ Tris- $\mathrm{HCl}$, $5 \mathrm{mM}$ Etilenodiamine Tetra-acetic Acid, 0.01\% Sodium Dodecil Sulfate and variable formamide concentration, according to Table 2). The hybridization occurred in a dark chamber at $42{ }^{\circ} \mathrm{C}$ for $8-10 \mathrm{~h}$. After this period, membranes were submerged in a washing buffer solution $(20 \mathrm{mM}$ Tris- $\mathrm{HCl}, 10 \mathrm{mM}$ Ethylenediamine Tetra-acetic Acid, $0.01 \%$ Sodium Dodecyl Sulfate and variable concentrations of $\mathrm{NaCl}$, according to Table 2) in a dark chamber at $48^{\circ} \mathrm{C}$ for $15 \mathrm{~min}$. They were also stained with 4'6- Diamidine-2Phenylindole (DAPI) for about $5 \mathrm{~min}$ and washed 


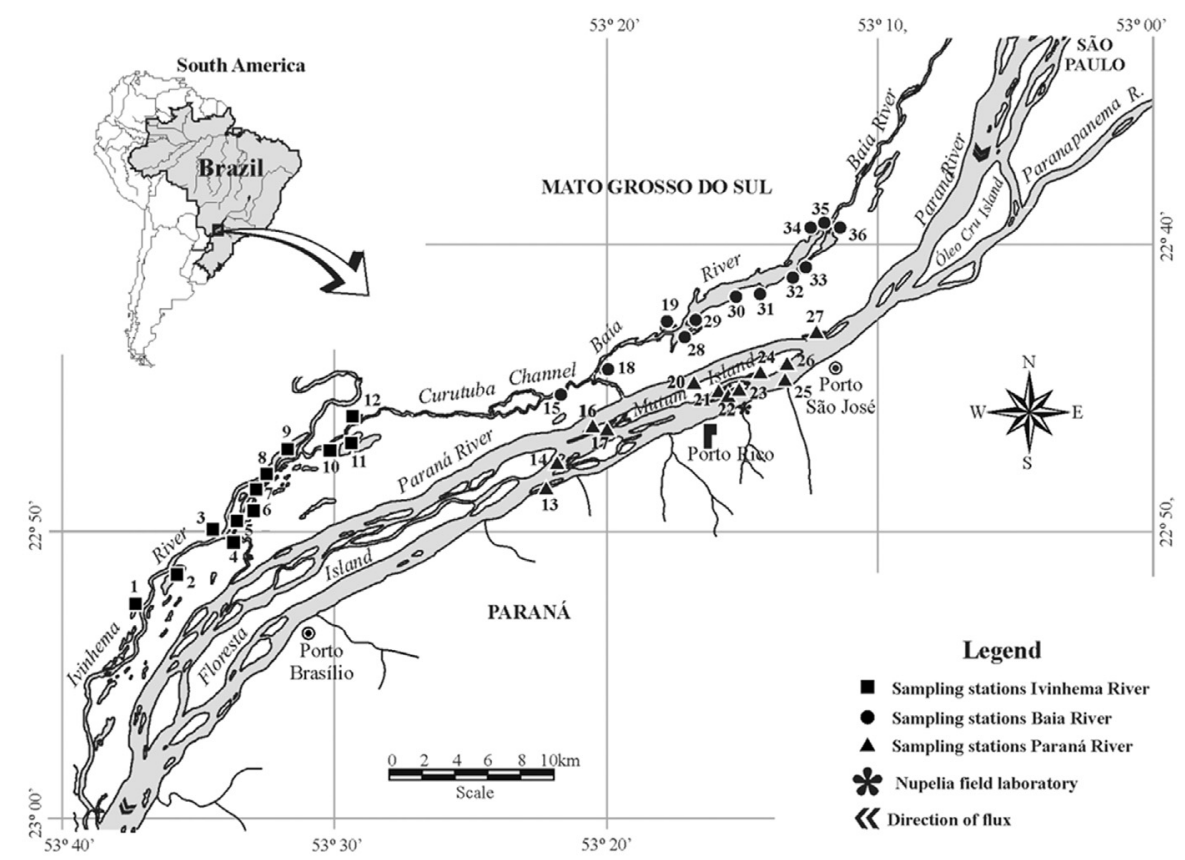

Figure 1 - Sampling sites 1) Peroba Lake; 2) Ventura Lake; 3) Zé do Paco Lake; 4) Ipoitã Channel; 5) Boca do Ipoitã Lake; 6) Patos Lake; 7) Capivara Lake; 8) Ivinhema River; 9) Finado Raimundo Lake; 10) Jacaré Lake; 11) Sumida Lake; 12) Cervo Lake; 13) Cortado Channel; 14) Pombas Lake; 15) Curutuba Channel; 16) Manezinho Backwater; 17) Osmar Lake; 18) Traíra Lake; 19) Guaraná Lake; 20) Bilé Backwater; 21) Leopoldo Backwater; 22) Genipapo Lake; 23) Clara Lake; 24) Pau Véio Backwater; 25) Paraná River; 26) Pousada Lake; 27) Garças Lake; 28) Baía River; 29) Fechada Lake; 30) Pousada das Garças Lake; 31) Porcos Lake; 32) Aurélio Lake; 33) Baía Channel; 34) Maria Luiza Lake; 35) Gavião Lake; 36) Onça Lake (Adapted from www.peld.uem.br).

three times in $80 \%$ alcohol. Each fraction of the filters received a mixture $4: 1$ of Vectashield and a solution of $7: 3$ glycerol: phosphate buffered saline solution and were analyzed using an epifluorescence microscope (Olympus, BX51).

We analyzed bacterial community structure according to its great domains Bacteria and Archaea, subdivisions of the phylum Proteobacteria: Alpha-proteobacteria, Betaproteobacteria, Gamma-proteobacteria, and the group Cytophaga-Flavobacterium (Table 2). We also used a control probe in order to identify unspecific stain and auto-fluorescence as proposed by Amann et al. (1995).

Some random bacterial cells were selected and measured to analyze bacterial biomass. Bacterial cell volume was calculated according to Fry (1990), and the conversion to biomass considered $1 \mu^{3}=3.5 \times 10^{-13}$ grams of Carbon according to Bjorsen (1936).

\section{Statistical analysis}

All abiotic variables - except $\mathrm{pH}$ - were $\log _{10}(\mathrm{x})$ modified and summarized in a Principal Component Analysis (PCA), in order to analyze the limnological differences among Subsystems and among rivers, channels and floodplain lakes. We used the "broken-stick" model to determine which axes would be considered in the analysis (Jackson, 1993).
Bacterial community structure was analyzed considering total bacterial density (cells $\mathrm{x} \mathrm{mL} \mathrm{m}^{-1}$ ) and frequency of main groups of bacteria, estimated in percentage in order to evaluate the importance of each group in relation to the entire bacteria community.

We analyzed the normality and homoscedasticity assumption by Shapiro-Wilk and Levene, respectively. When the assumptions were reached a parametric analysis of variance (ANOVA) was performed when the assumptions weren't significant we performed a non-parametric analysis of variance (Kruskal-Wallis) instead. We considered significant $\mathrm{p}<0.05$. For the variance analysis of bacterial community we applied the mean value of the three samples collected in each site when the subsystems and different rivers, channels, and floodplain lakes were considered as replicates.

The Mantel Test was performed in order to verify whether limnological dissimilarities also promotes bacterial community dissimilarities (Legendre and Legendre, 1998). We compared two dissimilarities matrices: limnological dissimilarities were analyzed using Euclidean Distance while bacterial community dissimilarities were analyzed using the Morisita-Horn index (Wolda, 1981). And the best subset of limnological data that most influence bacterial community was selected by Bio-Env analysis performed through R software (Clarke and Ainsworth, 1993).

In order to evaluate bacterial distribution according to the subset of limnological data that most influences bacte- 
Table 1 - Physical characteristics of the sampling sites in Paraná River Floodplain*.

\begin{tabular}{|c|c|c|c|c|}
\hline Sampling sites & Subsystem & Connection to the river & Area (ha) & Mean depth (m) \\
\hline Cortado Channel & Paraná & Channel & $* *$ & 1.3 \\
\hline Leopoldo Backwater & Paraná & Connected & 2.95 & 3.1 \\
\hline Manezinho Backwater & Paraná & Connected & 0.1 & 2.1 \\
\hline Garças Lake & Paraná & Connected & 14.1 & 2.0 \\
\hline Bilé Backwater & Paraná & Connected & $* *$ & 1.3 \\
\hline Pombas Lake & Paraná & Connected & $* *$ & 3.3 \\
\hline Pau-véio Backwater & Paraná & Connected & 3.0 & 1.8 \\
\hline Osmar Lake & Paraná & Unconnected & 0.006 & 1.1 \\
\hline Genipapo Lake & Paraná & Unconnected & 0.06 & 0.96 \\
\hline Clara Lake & Paraná & Unconnected & 0.91 & 1.2 \\
\hline Pousada Lake & Paraná & Unconnected & 12.7 & 0.39 \\
\hline Ipoitã Channel & Ivinhema & Channel & $* *$ & 3.2 \\
\hline Sumida Lake & Ivinhema & Connected & 67.4 & 1.6 \\
\hline Boca do Ipoitã Lake & Ivinhema & Connected & 2.3 & 3.6 \\
\hline Peroba Lake & Ivinhema & Connected & 12.2 & 3.1 \\
\hline Finado Raimundo Lake & Ivinhema & Connected & 84.9 & 3.2 \\
\hline Patos Lake & Ivinhema & Connected & 113.8 & 3.5 \\
\hline Zé do Paco Lake & Ivinhema & Unconnected & 2.7 & 3.9 \\
\hline Capivara Lake & Ivinhema & Unconnected & 7.2 & 3.6 \\
\hline Ventura Lake & Ivinhema & Unconnected & 89.8 & 2.16 \\
\hline Cervo Lake & Ivinhema & Unconnected & 7.81 & 2.0 \\
\hline Jacaré Lake & Ivinhema & Unconnected & 6.96 & 2.14 \\
\hline Baía Channel & Baía & Channel & $* *$ & 2.0 \\
\hline Curutuba Channel & Baía & Channel & $* *$ & 2.7 \\
\hline Gavião Lake & Baía & Connected & $* *$ & 2.2 \\
\hline Guaraná Lake & Baía & Connected & 4.2 & 2.1 \\
\hline Porcos Lake & Baía & Connected & 6.2 & 2.3 \\
\hline Onça Lake & Baía & Connected & 27.2 & 2.0 \\
\hline Maria Luiza Lake & Baía & Connected & 14.7 & 3.3 \\
\hline Aurélio Lake & Baía & Unconnected & 0.43 & 1.95 \\
\hline Fechada Lake & Baía & Unconnected & 7.5 & 2.46 \\
\hline Traira Lake & Baía & Unconnected & 0.47 & 2.1 \\
\hline Pousada das Garças Lake & Baía & Unconnected & 3.8 & 2.3 \\
\hline
\end{tabular}

*Data obtained from Research Report of Long Term Ecological Research (Fundação Universidade Estadual de Maringá).

**Missing data are not included in the report.

Table 2 - Probe sequences and concentrations of formamide and $\mathrm{NaCl}$ used in hybridization and washing buffer.

\begin{tabular}{|c|c|c|c|c|}
\hline Probe & Sequence & Form $(\%)^{*}$ & $\mathrm{NaCl}(\mathrm{mM}) * *$ & Reference \\
\hline EUB338R & 5' - 3GCT GCC TCC CGT AGG AGT - 3' & 30 & 102 & Amann et al., 1990 \\
\hline Arc344 & 5'- TCG CGC CTG CTG CIC CCC GT -3' & 30 & 102 & Raskin et al., 994 \\
\hline Alf986 & 5' - 3GG TAA GGT TCT GCG CGT T - 3’ & 30 & 102 & Neef, 1997 \\
\hline Bet42a & 5' - 3GC CTT CCC ACT TCG TTT - 3' & 30 & 102 & Manz et al., 1992 \\
\hline Gam42a & 5' - 3GC CTT CCC ACA TCG TTT - 3' & 30 & 102 & Manz et al., 1992 \\
\hline CF319a & 5'- 3TG GTC CGT GTC TCA GTA C - 3' & 35 & 80 & Manz et al., 1996 \\
\hline
\end{tabular}

*Formamide concentration in hybridization buffer.

** $\mathrm{NaCl}$ concentration in washing buffer. 
rial community we performed a Canonical Correspondence Analysis (CCA). The analyses were performed using Statistica 7.1 (Statsoft Inc. 2005), PcOrd 5 (Mccune and Mefford, 1999) and R software (R Development Core Team, 2011), Vegan package (Oksanen et al., 2011).

\section{Results}

The samples were collected in December/2010. This period correspond to flood period of the hydrological pulse in the upper Paraná River floodplain. The mean hydrological level during the sampling month was $2.94 \mathrm{~m}( \pm 0.22 \mathrm{~m})$, minimum of $2.20 \mathrm{~m}$ and maximum of 3.40 ; this means intermediary levels between high and low water phases.

We retained the two first axes of the PCA using the Broken-Stick criterion. Together, these axes represent $57.48 \%$ of data (axis $1=41.09 \%$; axis $2=16.38 \%$ ). In the first axis OSM $(r=0.85)$ and $\mathrm{NO}_{3}^{-}(r=0.83)$ presented higher positive correlations, while chlorophyll-a $(r=-0.70)$ negative correlation. In the second axis, alkalinity $(r=0.50)$ presented higher positive correlation and ISM $(r=-0.72)$ correlated negatively in this axis (Figure2).
Limnological differences of the three rivers comprising the floodplain allowed a clear division of the subsystems in PCA, mainly the Baía Subsystem (Figure 2). Only the first axe eigenvalues presented significant differences that distinguished the Baía Subsystem from the others $\left(\mathrm{F}_{(2 ; 33)}=15.3276 ; \mathrm{p}=0.00002\right)$. No significant differences were found among connect and unconnected floodplain lakes, channels and rivers in any PCA axis. Then, through limnological variables we were able to distinguish clearly the three subsystems, but not the different environment classifications, such as connected or unconnected lakes, rivers and channels. And the bacterial community structure may also follow this pattern.

Limnological data for each subsystem is shown in Table 3. Paraná Subsystem presented higher values of conductivity, TSM, OSM and alkalinity; Baía System presented higher values of total nitrogen and phosphorus. A higher value in turbidity was observed in Ivinhema Subsystem.

The non parametric variance analysis presented significant differences among subsystems in total bacterial density $\left(\mathrm{KW}-\mathrm{H}_{(2 ; 36)}=6,2748 ; \mathrm{p}=0,0434\right)$. The Baía Subsystem presented the highest bacterial density $7.79 \times 10^{6}$
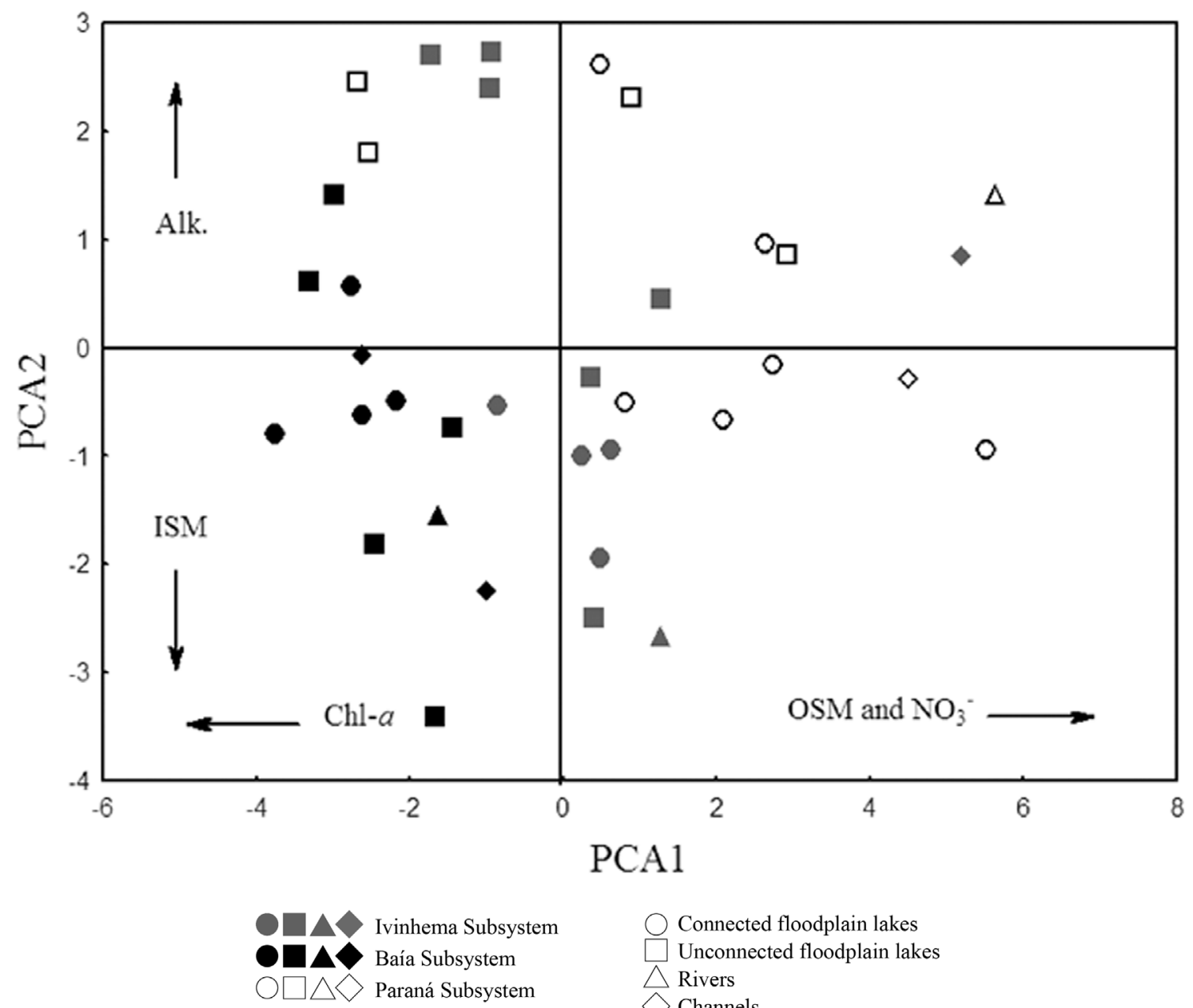

Connected floodplain lakes

$\square$ Unconnected floodplain lakes

$\triangle$ Rivers

$>$ Channels

Figure 2 - PCA performed with $\log (\mathrm{x})$ modified limnological data. Ordination of the scores for each sampling site in relation to axes 1 and 2 from PCA. 
Table 3 - Mean and standard deviation (SD) of limnological data in each subsystem.

\begin{tabular}{|c|c|c|c|c|c|}
\hline & Baía & Ivinhema & Paraná & $\mathrm{KW}-\mathrm{H}_{(2 ; 36)}$ & $\mathrm{p}$ \\
\hline Temp. $\left({ }^{\circ} \mathrm{C}\right)$ & $28.42 \pm 0.62$ & $28.12 \pm 0.80$ & $26.73 \pm 0.66$ & 19.6383 & $<0.01$ \\
\hline DO (mg/L) & $3.38 \pm 1.01$ & $4.4 \pm 1.64$ & $4.02 \pm 1.90$ & 3.1637 & 0.2056 \\
\hline $\mathrm{pH}$ & $5.78 \pm 0.22$ & $6.97 \pm 0.43$ & $6.42 \pm 0.41$ & 24.0122 & $<0.01$ \\
\hline Cond.(uS/cm) & $25.75 \pm 4.37$ & $41.25 \pm 6.82$ & $60.30 \pm 13.80$ & 28.5085 & $<0.01$ \\
\hline $\operatorname{Secchi}(\mathrm{m})$ & $0.66 \pm 0.15$ & $0.97 \pm 0.83$ & $1.55 \pm 1.46$ & 8.4455 & 0.0147 \\
\hline Turb (NTU) & $19.47 \pm 15.71$ & $21.21 \pm 19.66$ & $7.60 \pm 7.47$ & 9.0556 & 0.0108 \\
\hline $\mathrm{TSM}(\mu \mathrm{g} / \mathrm{L})$ & $0.77 \pm 0.49$ & $1.56 \pm 1.06$ & $1.98 \pm 1.72$ & 6.2129 & 0.0448 \\
\hline ISM (mg/L) & $0.57 \pm 0.45$ & $1.05 \pm 0.85$ & $1.18 \pm 1.14$ & 2.1388 & 0.3432 \\
\hline $\mathrm{OSM}(\mathrm{mg} / \mathrm{L})$ & $0.19 \pm 0.07$ & $0.51 \pm 0.24$ & $0.80 \pm 0.63$ & 17.8018 & $<0.01$ \\
\hline Alk.(mEq/L) & $142.00 \pm 24.81$ & $371.08 \pm 123.18$ & $454.77 \pm 140.53$ & 24.8889 & $<0.01$ \\
\hline Chl-a.( $\mu \mathrm{g} / \mathrm{L})$ & $13.95 \pm 11.44$ & $10.23 \pm 9.60$ & $15.89 \pm 32.49$ & 2.5243 & 0.2830 \\
\hline $\mathrm{TN}(\mu \mathrm{g} / \mathrm{L})$ & $952.33 \pm 177.36$ & $789.12 \pm 170.58$ & $808.42 \pm 431.80$ & 11.3226 & $<0.01$ \\
\hline $\mathrm{NO}_{3}(\mu \mathrm{g} / \mathrm{L})$ & $18.24 \pm 24.69$ & $38.89 \pm 38.82$ & $100.28 \pm 81.93$ & 10.8472 & $<0.01$ \\
\hline $\mathrm{NH}_{4}(\mu \mathrm{g} / \mathrm{L})$ & $27.62 \pm 24.88$ & $17.86 \pm 21.03$ & $40.57 \pm 32.49$ & 4.4505 & 0.1080 \\
\hline $\mathrm{TP}(\mu \mathrm{g} / \mathrm{L})$ & $59.81 \pm 19.05$ & $46.10 \pm 16.21$ & $49.97 \pm 70.74$ & 8.5251 & 00141 \\
\hline $\mathrm{PO}_{4}(\mu \mathrm{g} / \mathrm{L})$ & $9.05 \pm 3.32$ & $7.04 \pm 2.96$ & $6.85 \pm 1.93$ & 2.4193 & 0.2983 \\
\hline $\mathrm{DOC}(\mathrm{mg} / \mathrm{L})$ & $10.87 \pm 2.79$ & $*$ & $2.59 \pm 2.06$ & $* 5.3333$ & 0.0209 \\
\hline
\end{tabular}

*Due to problems in storage of samples, Ivinhema Subsystem DOC analysis weren't performed, $\left(\mathrm{KW}-\mathrm{H}_{(1 ; 8)}\right)$.

$\left( \pm 3.03 \times 10^{6}\right)$ cells $\times \mathrm{mL}^{-1}$, followed by the Ivinhema Subsystem $6.45 \times 10^{6}\left( \pm 3.17 \times 10^{6}\right)$ cells $\times \mathrm{mL}^{-1}$, and the lowest bacterial density was observed in the Paraná Subsystem $5.15 \times 10^{6}\left( \pm 3.34 \times 10^{6}\right)$ cells $\times \mathrm{mL}^{-1}$.

Bacterial density did not differ among river, channel, connected and unconnected floodplain lakes $\left(\mathrm{KW}-\mathrm{H}_{(3 ; 36)}=\right.$ 2.8069; $\mathrm{p}=0.4224)$. Although unconnected floodplain lakes presented the highest bacterial density $\left(7.11 \times 10^{6} \pm\right.$ $4.07 \times 10^{6}$ cells $\left.\times \mathrm{mL}^{-1}\right)$, followed by connected floodplain lakes $\left(6.68 \times 10^{6} \pm 2.83 \times 10^{6}\right.$ cells x mL $\left.\mathrm{mL}^{-1}\right)$, channels $(5.21 \mathrm{x}$ $10^{6} \pm 1.54 \times 10^{6}$ cells $\left.\times \mathrm{mL}^{-1}\right)$, and the lowest density was found in rivers $\left(3.93 \times 10^{6} \pm 2.41 \times 10^{6}\right.$ cells x mL $\left.\mathrm{mL}^{-1}\right)$.

Relative abundance of the two prokaryote domains, Bacteria and Archaea, was significantly different among subsystems, but only Bacteria differed significantly throughout rivers, channels, and floodplain lakes (Figure $3 \mathrm{~A})$.

Sampling sites in the Paraná Subsystem presented a high relative abundance of Bacteria and low relative abundance of Archaea, whereas sites in Ivinhema Subsystem presented an increase in relative abundance of Archaea allied to a decrease in Bacteria in relation to the Paraná Subsystem (Figure 3A). The Baía Subsystem sites, however, presented higher relative abundance to both Bacteria and Archaea.

Channels, followed by unconnected floodplain lakes presented higher relative abundance of Bacteria, whereas Archaea was observed in lower relative abundance in rivers, channels and lakes (Figure 3B).

Subdivisions of the Proteobacteria phylum Proteobacteri aand Cytophaga-Flavobacterium were significant different among subsystems (Figure 4A). The Paraná Subsystem presented higher relative abundance of Alphaproteobacteria and Beta-proteobacteria, while a lower relative abundance was observed for Gamma-proteobacteria. The Ivinhema Subsystem presented similar frequencies for all the bacterial groups studied and the Baía Subsystem presented the higher relative abundance of Beta- and Alphaproteobacteria, but differently from what was observed in Paraná System, the lowest relative abundance observed was for Cytophaga-Flavobacterium.

Among rivers, channels and connected and unconnected floodplain lakes only Beta-proteobacteria differed significantly (Figure 4B), it presented lowest relative abundance in the rivers, and was observed in higher relative abundance in channels and floodplain lakes. And although the difference was not statistically significant, the higher relative abundance of Gamma-proteobacteria was observed in the rivers $(17 \%)$ and the lowest in the unconnected floodplain lakes $(11 \%)$. The higher relative abundance of Beta-proteobacteria and lowest of CytophagaFlavobacterium were found in channels and connected lakes. In the unconnected floodplain lakes the highest relative abundance found was for Alpha-proteobacteria.

Biomass analysis was significantly different among the three rivers of the floodplain $\left(\mathrm{KW}-\mathrm{H}_{(2 ; 30)}=9.9744\right.$, $\mathrm{p}=0.0068)$, Paraná River presented the lowest bacterioplankton biomass, and the highest biomass was observed in the Baía River (Figure 5). Differences in bacterial cell sizes are presented in figure $\mathrm{S} 1$.

Mantel test permitted to assess that the bacterial community structure was significantly influenced by limnologi- 

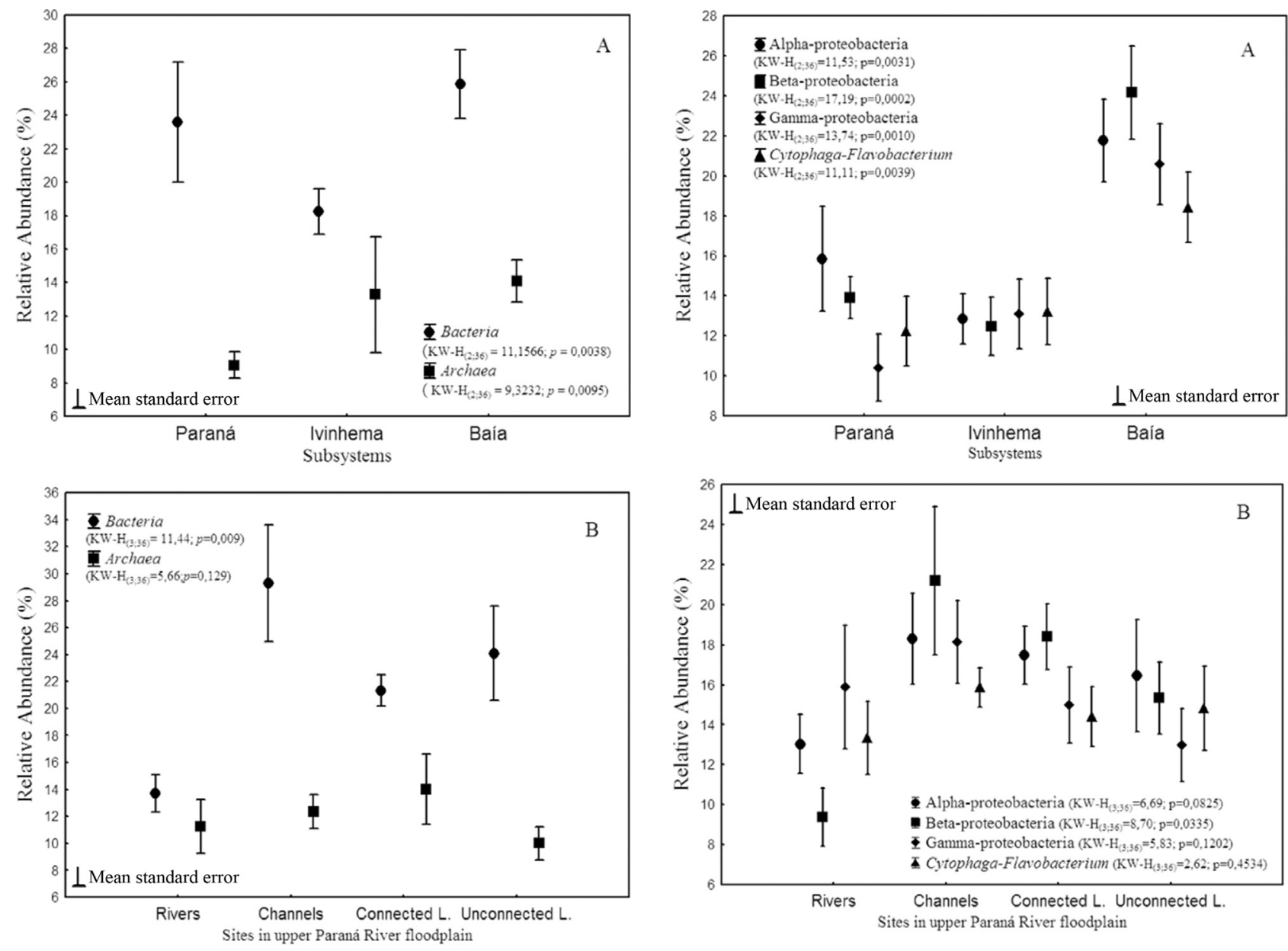

Figure 3 - Relative abundance of Bacteria and Archaea. (A) Among subsystems (B) Among rivers, channels and connected/unconnected floodplain lakes.

cal characteristics $(r=0.1922, \mathrm{p}=0.018)$. Bio-env analysis indicated that chlorophyll- $a$, TN, N-NH${ }_{4}{ }^{+}$and $\mathrm{PO}_{4}{ }^{3-}$ comprise the subset of the limnological variable that most correlated with bacterial community structure $(r=0.3542)$ in sampling sites.

The first axis of Canonical Correspondence Analysis was significant (0.006) and explained $22.9 \%$ of the data. Alpha-proteobacteria, Gamma-proteobacteria, and Cytophaga-Flavobacterium were positively grouped, and were correlated to the higher values of ammoniacal nitrogen. Beta-proteobacteria, however, were pooled negatively, and were correlated with higher values of $\mathrm{TN}, \mathrm{PO}_{4}{ }^{3-}$ and chlorophyll- $a$ (Figure 6).

\section{Discussion}

In most data on bacterial ecology in freshwater systems, the bacterial growth is attributed to higher concentrations of inorganic nutrients, mainly phosphorus and nitrogen (Kobayashi et al., 2009, Weisse and Macisaac, 2000). Subsystem distinction by PCA allowed the assessment that the three rivers comprising upper Paraná River

Figure 4 - Relative abundance of Proteobacteria and CytophagaFlavobacterium (A) among subsystems (B) among rivers, channels, and connected and unconnected floodplain lakes.

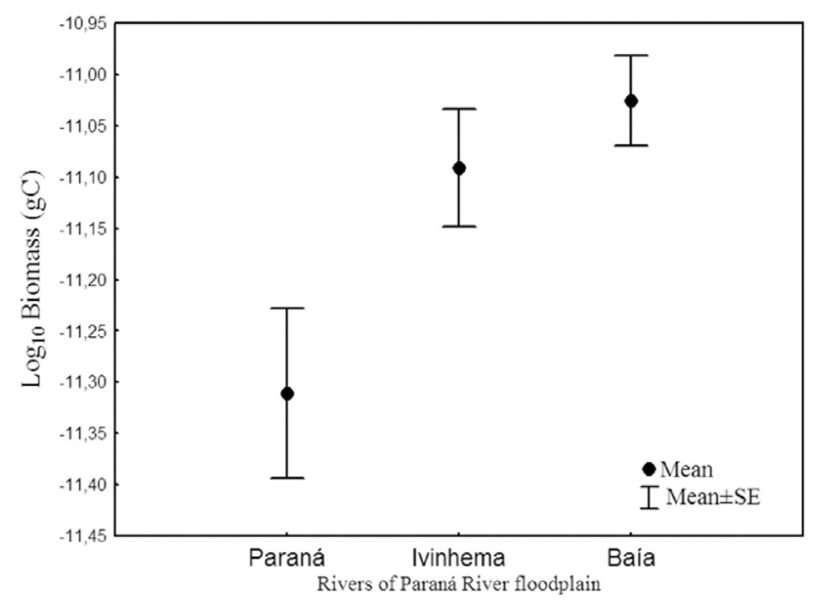

Figure 5 - Bacterial biomass in the rivers that compound the floodplain.

floodplain present very diverse limnological features, which influence directly channels and lakes connected to each one. However, the same analysis did not present dif- 

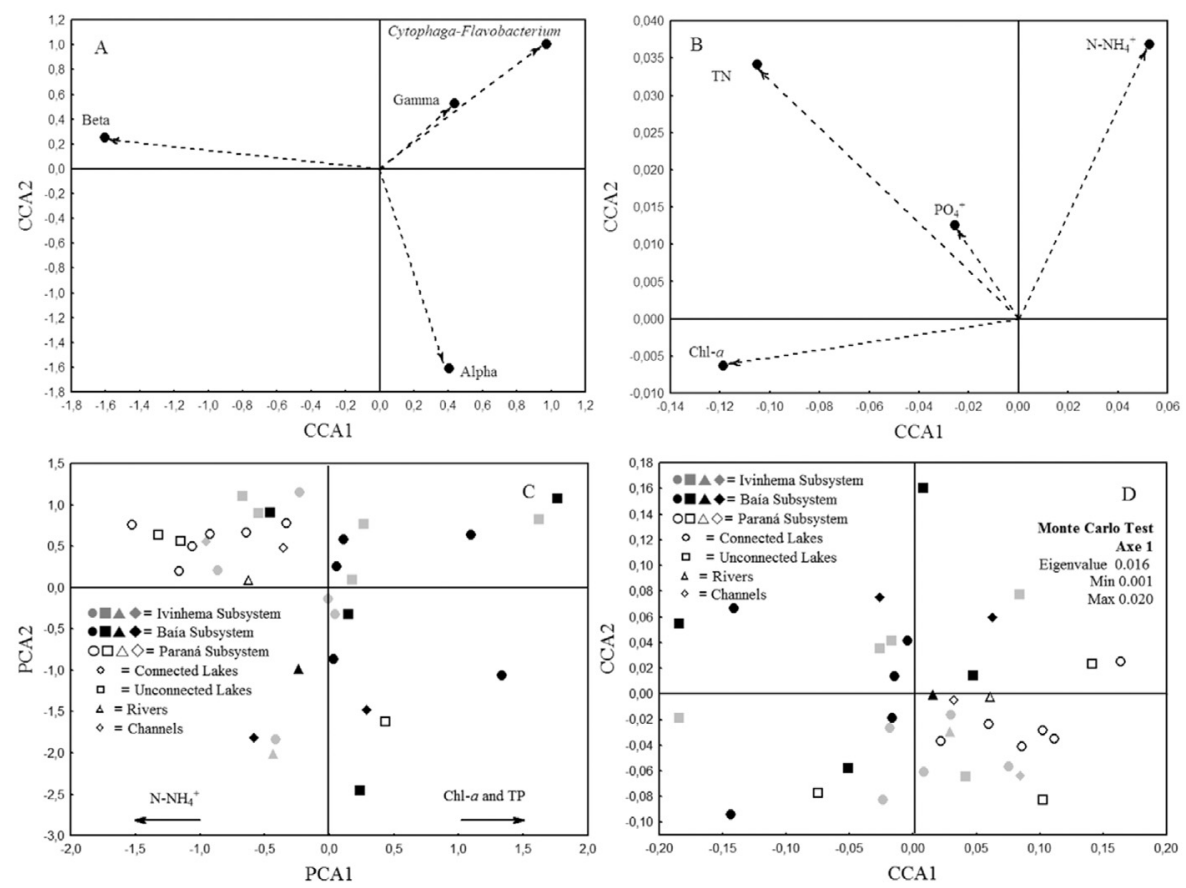

Figure 6 - Ordination of the two first axes of Canonical Correspondence Analysis (CCA). Scores ordination of axes 1 and 2 according to (A) Bacterial groups, (B) limnological variable; (C) physical and chemical data correlation ordination and (D) sampling sites.

ferences in rivers, channels and floodplain lakes with different connectivity to the rivers.

In a similar study microbial structure and functioning were examined during different hydrologic periods in glacial streams. Freimann et al. (2013) accessed three different catchments to cover an array of landscape features, including interconnected lakes, differences in local geology and degree of deglaciation. They also found that each catchment presented a distinct bacterial community structure and that it was linked to the physicochemical properties of the waters within each catchment.

In this study, bacterial structure was influenced mainly by chlorophyll- $a$, TN, N-NH${ }_{4}{ }^{+}$and $\mathrm{PO}_{4}{ }^{3}$, as determined by Bio-Env analysis. The limnological differences among subsystems might have caused the significant difference in total bacteria density and bacterial structure in the floodplain.

The higher concentrations of phosphorus and nitrogen observed in the Baía Subsystem could be the reason for the highest bacterial density found in these environments. Although total bacteria density shows significant differences throughout subsystems, these differences may not be great enough to cause any ecological effect in the floodplain. However, the reduction in nutrient contents in the Paraná River, due to the building of the Porto Primavera Dam (Roberto et al., 2009), could have compromised bacterial growth, generating small bacterial cells that, together to the low bacterial densities, could have caused the lowest bacterial biomass in this river. And this could probably have an influence on the microbial food web in this system.
Archaea domain comprises organisms characteristically found at great depths, where anaerobic metabolism is commonly observed. This domain presented higher relative abundance in Baía Subsystem. In freshwater systems these organisms are found less frequently in limnetic sediments (Borrel et al., 2012; Chan et al., 2005, Schwarz et al., 2007), where they represents about $1 \%$ of prokaryotes communities in lake sediments (Schwarz et al., 2007). Still, there are a lot of controversies regarding the Archaea domain. This group has been found in large abundances in oceans (Karner et al., 2001). Maybe a technique different from the one used in this study might provide better information about this high occurrence of Archaea in this floodplain.

Several studies carried out in temperate freshwater systems observed relative abundance of Bacteria domain higher than 50\% (Cottrell and Kirchman, 2000). There is two possible explanation for the low frequency of Bacteria found in this study: i) it is a natural characteristic of the environment, if so, further studies are required in order to investigate the reasons that this floodplain shows high occurrence of Archaea and low frequency of Bacteria or ii) the EUB338 probe used in this study was insufficient to estimate the entire Bacteria domain.

According to Daims et al. (1999), this probe excludes from a study groups Planctomycetales and Verrucomicrobia that are important constituents in aquatic systems. These authors also developed two new probes, EUB338 II and EUB338 III, that should have been used together with EUB338. Although these probes are not commonly ap- 
plied, used together, they might provide a more accurate estimate of all Bacteria domain. Therefore, if this system is characterized by having high occurrences of Planctomycetales and Verrucomicrobia, accordingly, the frequency of Bacteria in this study is smaller than what is commonly found. Lemke et al. (2009) reported 7\% of clones of Verrucomicrobia in the Paraná River during high water phase.

Yannarell and Triplett (2005) have found that environmental features and regional changes could determine bacterial communities in temperate lakes in Northern hemisphere. This study presented differences in relative abundance of Proteobacteria and Cytophaga-Flavobacterium among subsystems, but not among rivers, channels and connected or unconnected lakes. Once again it is suggest that the rivers' features are the main determiners of bacterial community structure in this floodplain. Then we will try to elucidate a few aspects that might have caused these differences in this floodplain system.

Long-term studies have attributed an increase in transparency to the dams constructed upstream of the floodplain, allied to a decrease in nutrient content (Roberto et al., 2009). This anthropic impact over the floodplain might have influenced the bacterial community structure in the Paraná River. The higher relative abundance of Alpha-proteobacteria and low relative abundance of Gamma-proteobacteria in this subsystem should be related mainly to the low availability of nutrients observed in this river.

According to Besemer et al. (2005), higher content of inorganic nutrient and lower content of organic matter could lead to a high competition among bacteria communities leading to low OTU (operational taxonomic units) richness. Some Alpha-proteobacteria present slow growth and are very well adapted to low concentrations of oxygen (Imhoff, 2006), so it could explain the occurrence of this cluster in the Paraná River, where the nutrient content are low, and Alpha-proteobacteria have competitive advantage over the other Proteobacteria. Changes have already been reported in zooplankton and phytoplankton communities due to the building of the Porto Primavera Dam. The zooplankton community presented a decrease in species richness after the Porto Primavera impoundment due to alterations in hydrology (Lansac-Toha et al., 2009). Long periods of isolation (when the flood is not enough to connect the rivers and the lakes) might provide alterations in bacterial communities, mainly due to predation.

According to Rodrigues et al. (2009), the phytoplankton community decreased in species richness in the Paraná River after the building of the dam. They also reported an increase in density of phytoplankton in the three rivers in the floodplain and a greater contribution of cyanobacteria than that of diatoms to species richness. Pinhassi et al. (2004) suggested that differences in density and diversity of phytoplankton species can influence bacterial composition. According to these authors, diatom-dominated microcosms show higher occurrence of Flavobacteriaceae, Alpha-proteobacteria, and Gamma-proteobacteria. Further and more accurate studies are required to understand how these communities influence bacterial community structure in floodplain systems.

Gamma-proteobacteria are characterized by having opportunistic organisms that are found in greater densities in sites with great availability of nutrients, mainly phosphorus (Bouvier and Del Giorgio, 2002), such as Baía Subsystem. This subsystem is characterized by its surroundings, which are comprised of anthropized pastures and fields (Fundação Universidade Estadual de Maringá, 2000) that during high water phase comprise an extensive lowland area. When this area is flooded, a great amount of organic matter is discharged into the aquatic systems. According to Azevedo et al. (2005), the organic carbon found in higher quantity in the Baía system comes mostly from the lowland area, and is comprised mainly of fulvic acid.

There is a change in planktonic bacterial community in accordance to the origin and quality of available DOC to bacterial growth (Crump et al., 2003, Teixeira et al., 2007). In the Baía subsystem the higher contents of nitrogen and phosphorus were found, that allied with available organic carbon quality, might have determined the higher relative abundance of Proteobacteria and CytophagaFlavobacterium in this subsystem.

The Ivinhema subsystem is within an Environmental Protection Area, the Parque Estadual das Várzeas do Rio Ivinhema, created as a compensatory measure for the construction of the Porto Primavera Dam. Bacterial divisions were well distributed in this system, perhaps because it is probably the most stable subsystem and it is not susceptible to anthropic impacts such as dam regulation and pastures.

Throughout rivers, lakes and channels, we observed significant differences only in Beta-proteobacteria. Although we did not observe significant differences, the relative abundance of Gamma-proteobacteria was higher in rivers than in the unconnected lakes. Probably the flux promoted a competitive advantage to this group in the rivers, once the organisms present in the Gamma-proteobacteria division are known by their opportunistic characteristics. In unconnected lakes, the absence of flux might have promoted the development of a higher relative abundance of Alpha-proteobacteria. Despite the fact that this division does not require high nutrient concentration, perhaps the lentic environment enabled their growth. Similar results were found by Lemke et al. (2009) that reported that 14\% of OTU registered in the upper Paraná River floodplain were only found in lotic habitats, and that includes the Gamma-proteobacteria division.

More detailed studies about each subsystem, as well as the use of more specific probes could elucidate functional role of the bacterial community in the nutrient cycle and energy flux to the ecosystem. And other selective factors in the community; such as dominance, selective preda- 
tion, competition and susceptibility must also be considered in future studies.

This is the first large-scale study about bacterial community structure in the upper Paraná River floodplain. Through it, it was possible to determine which differences in limnological conditions would have influence in the bacterial community; that the different rivers that comprise the floodplain and its limnological features were the main determiner of the community more than physical features of the rivers, channels, and connected and unconnected lakes. Since two of the three subsystems analyzed were subject to anthropic alterations, differences in bacterial community structure might be influenced by these impacts as well.

\section{Acknowledgments}

This study was undertaken with support from CAPES. We thank CNPq and CAPES by the financial support; and the Núcleo de Pesquisas em Limnologia, Ictiologia e Aquicultura (Nupélia), The Post-Graduate Program in Ecology (PEA-UEM) for the infrastructure and support.

\section{References}

Amann RI, Binder BJ, Olson RJ, Chisholm SW, Devereux R, Stahl DA (1990) Combination of 16S rRNA-targeted oligonucleotide probes with flow cytometry for analyzing mixed microbial populations. Appl Environ Microb 56:1919-1925.

Amann RI, Ludwig W, Schleifer KH (1995) Phylogenetic Identification and In Situ Detection of Individual Microbial Cells without Cultivation. Microbiol Rev 59:143-169.

Anésio AM, Abreu PC, Esteves FA (1996) Influence of the Hydrological Cycle on the Bacterioplankton of an Impacted Clear Water Amazonian Lake. Microbial Ecol 34:66-73.

Azam F, Fenchel T, Field JG, Gray JS, Meyer-Reil LA, Thingstad F (1983) The ecological role of water-column microbes in the sea. Mar Ecol Prog Ser 10:257-263.

Azevedo JC, Teixeira MC, Santos AM, Leandrini JA, Pagioro TA (2008) Caracterização espectroscópica da matéria orgânica dissolvida da planície de inundação do alto rio Paraná. Oecol Bras 12:66-77.

Besemer K, Moeseneder MM, Arrieta JM, Herndl GJ, Peduzzi P (2005). Complexity of bacterial communities in a RiverFloodplain System (Danube, Austria). Appl Environ Microb 71:609-620.

Bjorsen BK (1936) Automatic Determination of Bacterioplankton Biomass by Image Analysis. Appl Environ Microb 51:1199-1204.

Borrel G, Lehours AC, Crouzet O, Jézéquel D, Rockne K, Kulczac A, Duffaud E, Joblin K, Fonty G (2012) Stratification of Archaea in the deep sediments of a freshwater meromitic lake: Vertical shift from methanogenic to uncultured Archaeal lineages. Plos One 7:1-14.

Bouvier T, Del Giorgio PA (2002) Compositional changes in free-living bacterial communities along a salinity gradient in two temperate estuaries. Limnol Oceanogr 47:453-470.

Carmouze JP (1995) O Metabolismo dos Ecossistemas Aquáticos. Fundamentos Teóricos, Métodos de Estudo e Análises Químicas. Edgard Blücher/Fapesp, São Paulo.
Carvalho P, Thomaz SM, Bini LM (2003) Effects of water level, abiotic and biotic factors on bacterioplankton abundance in lagoons of a tropical floodplain (Paraná River, Brazil). Hydrobiol 510:67-74.

Chan OC, Claus P, Casper P, Ulrich A, Lueders T, Conrad R (2005) Vertical distribution of structure and function of the methanogenic Archaeal community in Lake Dagow sediment. Environ Microbiol 7:1139-1149.

Clarke KR, Ainsworth M (1993) A method of linking multivariate community structure to environmental variables. Mar Ecol Progr Ser 92:205-219.

Cotner JB, Biddanda BA (2002) Small players, large role: microbial influence on biogeochemical processesin pelagic aquatic ecosystems. Ecosys 5:105-121.

Cottrell M, Kirchman DL (2000) Community composition of marine bacterioplankton determined by $16 \mathrm{~S}$ rRNA gene clone libraries and fluorescence in situ hybridization. Appl Environ Microb 66:5116-5122.

Crump BC, Kling GW, Bahr M, Hobbie JE (2003) Bacterioplankton community shifts in an artic lake correlate with seasonal changes in organic matter source. Appl Environ Mircrob 69:2253-2268.

Daims H, Brühl A, Amann R, Schleifer KH, Wagner M (1999) The domain-specific probe EUB338 is insufficient for the detection of all Bacteria: Development and evaluation of a more comprehensive probe set. Syst Appl Microbiol 22:434-444.

Freimann R, Burgmann H, Findlay SEG, Robinson CT (2013) Bacterial structures and ecosystem functions in glaciated floodplains: contemporary states and potential future shifts. The ISME Journal 7:2361-2373

Fry JC (1990) Direct methods and biomass estimation. In: Grigorova R., Norris, J.R. (eds) Methods in Microbiology. Academic Press Ltd, London, pp 41-85.

Fundação Universidade Estadual De Maringá. 2000. Relatório Anual/PELD. A planície alagável do alto rio Paraná Sitio 6. Descrição dos locais de amostragem Available at: (http://www.peld.uem.br/Relat2000/2_2_CompBioticoDes LocAmost.PDF). Accessed 26 June 2013.

Golterman HL, Clymo RS, Ohnstad MAM (1978) Methods for Physical and Chemical Analysis of Fresh Waters. Blackwell Scientific Publication, London.

Haukka K, Heikkinen E, Kairesalo T, Karjalainen H, Sivonen K (2005) Effect of humic material on bacterial community composition in boreal lakes and mesocosms. Environ. Microbiol 7:620-630.

Imhoff JF (2006) Chapter 3.1.1. The Phototrophic AlphaProteobacteria. In: Dworkin M, Falkow S, Rosenberg B, Schleifer KH, Stackebrandt E. (eds) The Prokaryotes. Springer, New York, pp 41-64.

Jackson DA (1993) Stopping rules in principal component analysis: a comparison of heuristical and statistical approaches. Ecology 74:2204-221.

Karner MB, deLong EF, Karl DM (2001) Archaeal dominance in the mesopelagic zone of the Pacific Ocean. Nature 409:507-510.

Kent AD, Jones SE (2006) Experimental manipulations of microbial food web interactions in a humic lake: shifting biological drivers of bacterial community structure. Environ Microbiol 8:1448-1459. 
Kobayashi T, Ryder DS, Gordon G, Shannon I, Ingleton T, Carpenter M, Jacobs SJ (2009) Short-term response of nutrients, carbon and planktonic microbial communities to floodplain wetland inundation. Aqua Ecol 43:843-858.

Lansac-Toha FA, Bonecker CC, Velho LFM, Simões NR, Dias JD, Alves GM, Takahashi EM (2009) Biodiversity of zooplankton communities in Upper Paraná River floodplain: interannual variation from long term studies. Braz J Biol 69(Suppl):539-549.

Legendre P, Legendre L (1998) Numerical Ecology. Elsevier, Amsterdam, $853 \mathrm{pp}$.

Lemke MJ, Lienau EK, Rothe J, Pagioro TA, Rosenfeld J, DeSalle R (2009) Description of freshwater bacterial assemblages from the upper Paraná river floodpulse system, Brazil. Microbial Ecol 57:94-103.

Mackereth FYH, Heron J, Talling JJ (1978) Water analysis: some revised methods for limnologists. Freshwater Biol 36:1-120.

Manz W, Amann R, Ludwig W, Vancanneyt M, Schleifer KH (1996) Application of a suite of 16S rRNA-specific oligonucleotide probes designed to investigate Bacteria of the phylum cytophaga-flavobacter-bacteroides in the natural environment. Microbiol 142:1097-1106.

Manz W, Amann R, Ludwig W, Wagner M, Schleifer KH (1992) Phylogenetic oligodeoxynucleotide probes for the major subclasses of Proteobacteria: problems and solutions. Syst Appl Microbiol15:593-600.

Mccune B, Mefford MJ (1999) Pc-Ord. Multivariate Analysis of Ecological Data. Version 5.0. MJM Software, Gleneden Beach, Oregon.

Neef A (1997) Anwendung der in situ Einzelzell-Identifizierung von Bakterien zur Populations analyse in komplexen mikrobiellen Biozönosen. Doctoral Thesis, Technische Universität München.

Nelson CE (2009) Phenology of high-elevation pelagic Bacteria: the roles of meteorologic variability, catchment inputs and thermal stratification in structuring communities. The ISME Journal 3:13-30.

Newton RJ, Kent AD, Triplett EW, McMahon KD (2006) Microbial community dynamics in a humic lake: differential persistence of common freshwater phylotypes. Environ Microbiol 8:956-970.

Oda Y, Star B, Huisman LA, Gottschal JC, Forney LJ (2003) Biogeography of the purple nonsulfur bacterium Rhodopseudomonas palustris. Appl Environ Microbiol 69:51865191.

Palijan G, Fuks D (2006) Alternation of factors affecting bacterioplankton abundance in the Danube River floodplain (Kopacki Rit, Croatia). Hydrobiologia 560:405-415.

Papke RT, Ramsing NB, Bateson MM, Ward DM (2003) Geographical isolation in hot spring cyanobacteria. Environ Microbiol 5:650-659.

Pernthaler J, Glöckner FO, Schönhuber W, Amann R (2001) Fluorescence insitu hybridization. In: J. Paul (ed). Methods in Microbiology: Marine Microbiology. Academic Press Ltd, London $666 \mathrm{pp}$.

Pinhassi J, Sala MM, Havskum H, Peters F, Guadayol O, Malits A, Marrasé C (2004) Changes in Bacterioplankton Composition under different Phytoplankton Regiments. Appl Environ Microbiol 70:6753-6766.
R Development Core Team (2011) R: A language and environment for statistical computing. R Foundation for Statistical Computing, Vienna, Austria. ISBN 3-900051-07-0, URL http://www.R-project.org/.

Raskin L, Stromley JM, Rittmann BE, Stahl DA (1994) Groupspecific 16S rRNA hybridization probes to describe natural communities of methanogens. Appl Environ Microbiol 60:1232-1240.

Roberto MC, Santana NF, Thomaz SM (2009) Limnology in the Upper Paraná River floodplain: large-scale spatial and temporal patterns, and the influence of reservoirs. Braz J Biol 69(Suppl):717-725.

Rodrigues LC, Train S, Bovo-Scomparin VM, Jati S, Borsalli CCJ, Marengoni E (2009) Interannual variability of phytoplankton in the main rivers of the upper Paraná River floodplain, Brazil: influence of upstream reservoirs. Braz J Biol 69(Suppl):501-516.

Schwarz JIK, Eckert W, Conrad R (2007) Community structure of Archaea and Bacteria in a profundal lake sediment Lake Kinneret (Israel). Syst Appl Microbiol 30:239-254.

Shade A, Kent AD, Jones SE, Newton RJ, Triplett EW, McMahon KD (2007) Interannual dynamics and phenology of bacterial communities in a eutrophic lake. Limnol Oceanogr 52:487494.

Statsoft Inc. (2005). Statistica (data analysis software system). Version 7.1.

Teixeira MC, Santana NF, Azevedo JCR, Pagioro TA (2011) Bacterioplankton features and its relations with doc characteristics and other limnological variables in Paraná river floodplain environments (PR/MS-Brazil). Braz J Microbiol 42:897-908.

Thomaz SM, Bini LM, Bozelli RL (2007) Floods increase similarity among aquatic habitats in river-floodplain systems. Hydrobiologia 579:1-13.

Tockner K, Malard F, Ward JV (2000) An extension of the flood pulse concept. Hydrol Process 14:2861-1883.

Weisse T, Macisaac E (2000) Significance and fate of bacterial production in oligotrophic lakes in British Columbia. Can J Fish Aquat Sci 57:95-105.

Wetzel RG, Likens GE (1990) Limnological Analyses. Springer-Verlag, New York, 391 pp.

Whitaker RJ, Grogan DW, Taylor JW (2003) Geographic barriers isolate endemic populations of Hiperthermophilic Archea. Science 301:976-978.

Wolda H (1981) Similarity indices, sample size and diversity. Oecologia (Berl) 50:296-302.

Yannarell AC, Triplett EW (2005) Geographic and environmental sources of variation in lake bacterial community composition. Appl Environ Microb 71:2:227-239.

Zagatto EAG, Jacintho AO, Reis BF, Krug FJ, Bergamin H, Pessenda LCR, Mortatti J, Giné MF (1981) Manual de Análises de Plantas Empregando Sistemas de Injeção em Fluxo. Universidade de São Paulo, Piracicaba.

Oksanen J., Blanchet FG, Kindt R, Legendre P, O'Hara RB, Simpson GL, Solymos P, Stevens MHH, Wagner H. 2011. Vegan: Community Ecology Package. R package version 1.17-6. Available at http://CRAN.R-project.org/package=vegan Statsoft 2005 .

All the content of the journal, except where otherwise noted, is licensed under a Creative Commons License CC BY-NC. 